\title{
EFFECT OF PRO AND PRE -BIOTIC SUPPLEMENTATIONS IN WEANING FOODS ON SOME MINERAL ABSORPTION
}

(Received : 29.7. 2014)

\author{
By \\ N.A. Elbostany \\ Special Foods and Nutrition Department, Food Technology Research Institute, \\ Agricultural Research Center, Giza, Egypt.
}

\begin{abstract}
The purpose of the present study was to examine the potential synergistic effect of prebiotics and probiotics combination (synbiotics) on mineral absorption and bone strength in weaning ages. Forty two of Western strain male rats aged two months were divided into 7 treatment groups of equal mean weights $60 \pm 5 \mathrm{~g}$ ( 6 rats/ group) as follows: group 1: fed on basal diet (reference group), group 2: fed on baby cereals food (control group),group 3: fed on baby cereals food supplemented with Bifidobacterium bifidum $(\mathrm{Bb})$ at a concentration of $8.95 \mathrm{log} \mathrm{cfu} / \mathrm{g}$, group 4: fed on baby cereals food supplemented with dried powder of Jerusalem artichoke tubers (Ja) at a concentration of 5\%, group 5: fed on baby cereals food supplemented with $\mathrm{Ja}$ at a concentration of $5 \%+\mathrm{Bb}$ at concentration of 8.95 $\log \mathrm{cfu} / \mathrm{g}$, group 6: fed on baby cereals food supplemented with Ja at a concentration of $10 \%$, and group 7:fed on baby cereals food supplemented with $\mathrm{Ja}$ at a concentration of $10 \%+\mathrm{Bb}$ at concentration of $8.95 \mathrm{log} \mathrm{cfu} / \mathrm{g}$. The experimental period lasted 5 weeks. At the fifth week, a controlled metabolic study was carried out.

The obtained results indicated that bifidobacterial count was stable during storage for 6 months especially in the formula which contains $10 \%$ of Ja. Baby foods supplemented with prebiotic and / or probiotic increased the absorption and the retention of $\mathrm{Ca}$ and $\mathrm{P}$ especially at high dose of prebiotic (100 g/kg diet) and combined with bifidobacteria (group 7). Mg balance and retention showed marked improvement in all treatment groups with highest values in groups 5 and 7 . Concerning mineral contents in femurs, there were significant increases in all treatment groups with higher values in group 7 for $\mathrm{Ca}$ and $\mathrm{Mg}$ and in groups 5 and 7 for $\mathrm{P}$ relative to the control group or reference group.

In conclusion, supplementation the baby cereal foods with bifidobacteria and Jerusalem artichoke as a source of inulin had a beneficial effect on mineral absorption and retention which have a positive impact on bone strength, particularly at $10 \%$ of Jerusalem artichoke.
\end{abstract}

Key words : Bifidobacterium bifidum, inulin, mineral absorption, synbiotics.

\section{INTRODUCTION}

In recent years, there has been a significant increase in research on the characterization and verification of potential health benefits associated with the use of probiotics and prebiotics. Micro-organisms most commonly used as probiotics belong to the heterogeneous group of lactic acid bacteria (Lactobacillus, Enterococcus, ) and to the genus Bifidobacterium (FAO/WHO, 2001). There is a strong evidence indicating that probiotics have preventive and therapeutic effectiveness on pathologies in pediatrics such as acute diarrhea (Dutta et al. 2011), and allergic pathology (Hurre et al. 2008), constipation (Nader and Youssef, 2007), inflammatory bowel disease (Steed et al., 2010),
Helicobacter pylori infection (Sykora et al., 2004).

Prebiotic are non-active food constituents that are non-digestible by digestive enzymes in humans and shift to the colon and are then selectively fermented. The benefit to the host is mediated during selective stimulation of the growth and/or activity of one or a limited number of bacteria. The essential end components of carbohydrate metabolism are short chain fatty acids, particularly acetic acid, propionic acid and butyric acid, which are used by the host organism as an energy source (AlSheraji et al. (2013). Lactulose, galactooligosaccharides, fructooligosaccharides, inulin and its hydrolysates, maltooligosaccharides, and 
resistant starch are prebiotics normally used in the human diet.

Numerous studies have shown that some prebiotics, alone or in blends, have health benefits and reduction of several diseases such as allergies in infants, colorectal cancer, hypercholesterolemia, hyperlipidemia, diabetes and obesity (Al-Sherajiet al.,2013).

Some plants are considered good source of prebiotics such as inulin. Inulin occurs as an energy reserve in various plants, in particular in those of composite family such as chicory, Jerusalem artichoke tubers and dahlia (Leclercq and Hageman, 1993). Jerusalem artichoke tubers (Helianthus tuberosus) is considered one of the most interesting potential source of fructose. Its importance was related first to its high content of inulin (Chabbert et al., 1983).

Actually, the mixtures of probiotics and prebiotics are often used in food products in order to take advantage of their synergic effects by both ensuring survival of delivered probiotics and stimulating the growth of selected indigenous bacteria. Thus, these mixtures are called synbiotics (Al-Sherajiet al., $2012 \mathrm{a}$ and b).

Breastfed infants are generally healthier than formula-fed infants, especially with respect to their ability to fend off infections. Some of the health benefits of human milk have been attributed partly to factors that modulate the development of a normal gut microbiota.These factors called human milk oligosaccharides (HMOS) (Newburg, 2005).

Hence, the development of improved infant formulas has focused on emulating the beneficial effects of breast milk by, among other approaches, supplementing formulas with specific probiotics or oligosaccharides and inulin (prebiotics) that selectively stimulate the growth or metabolic activity of potentially beneficial indigenous bacteria such as bifidobacteria (Chouraqui et al., 2008).
Several studies suggested that food supplements containing probiotic bacteria and /or prebiotics have beneficial effects on mineral absorption, $\mathrm{Ca}$ and $\mathrm{Mg}$ (Demigné et al., 2008) as well as Fe (Tako et al., 2008).

So, the present study was conducted in order to evaluate if baby food cereals fortified with bifidobacteria alone or with Jerusalem artichoke as a source of inulin (prebiotic) have the positive effect on $\mathrm{Ca}, \mathrm{Mg}$ and $\mathrm{P}$ absorption and their bioavailability in bones.

\section{MATERIALS AND METHODS}

\subsection{Preparing the formulas of baby cereals}

- All materials used for processing of formulas of baby cereals were taken from the Arab company for medicinal food factory. Ismailia, Egypt.

- The ingredients of baby cereal formulas are shown in Table (1).

- Bifidobacterium bifidum (Bb-12) were obtained from Chr.Hansn-Denemark. (Freeze- dried Bifido Bactria were prepared according to the method of Saarela et al. (2006).

- Jerusalem artichoke tubers (Helianthus tuberosus) were obtained from Horticultural Researh Institute, Agricultural Research Center, Dokki,Giza.

- All formulas were prepared and dried using Drum drier according to the method of (Perez-Conesa et al., 2002). After drying the formulas, thebifidobacteria were added under a septic condition. The end products were packaged in five layer bags with modified atmosphere under nitrogen gas.

\subsection{Chemical analysis of baby cereal formulas}

- The chemical compositions of different formulas of baby cereals were determined according to AOAC (2005).

- The inulin content was extracted and

Table (1): The composition of baby cereal formulas.

\begin{tabular}{|c|c|c|c|c|c|c|}
\hline Ingredients \% & F1 & F 2 & F3 & F4 & F5 & F6 \\
\hline Rice flour & $\mathbf{7 0}$ & 67 & 65 & 62 & 60 & 57 \\
\hline Skimmed milk & 8 & 8 & 8 & 8 & 8 & 8 \\
\hline Soy isolate & 5 & 5 & 5 & 5 & 5 & 5 \\
\hline Lecithin & 1 & 1 & 1 & 1 & 1 & 1 \\
\hline Sun flower oil & 3 & 3 & 3 & 3 & 3 & 3 \\
\hline Jerusalem artichoke & - & - & 5 & 5 & 10 & 10 \\
\hline Freeze dried Bifido bacteria* & - & 3 & - & 3 & - & 3 \\
\hline Tri calcium phosphate & 0.3 & 0.3 & 0.3 & 0.3 & 0.3 & 0.3 \\
\hline Sugar & 8 & 8 & 8 & 8 & 8 & 8 \\
\hline Vitamins and Minerals mixture & 4.7 & 4.7 & 4.7 & 4.7 & 4.7 & 4.7 \\
\hline Total & 100 & 100 & 100 & 100 & 100 & 100 \\
\hline
\end{tabular}

*3 g of Bifidobacterium bifidum contain $8.95 \log \mathbf{~ c f u / g}$. 
determined by HPLC according to the method of Molnar-Perl (2000).

\subsection{Bifidobacterium bifidum count}

Bifidobacterium bifidum (Bb-12) counts were determined according to Dave and Shah (1996), using modified MRS agar supplemented with $0.05 \%$ L-cysteine and $0.3 \%$ lithium chloride. The plates were anaerobically incubated at $37^{\circ} \mathrm{Cfor} 48 \mathrm{hrs}$

\subsection{Biological assay}

Forty two of the Western strain male rats aged two months with an initial body weight of approximately $60 \pm 5 \mathrm{~g}$ were housed in an animal house of Ophthalmology Research Institute at 12-h light/dark cycle in a temperature and humidity-controlled room. The animals were allowed free access to feed on basal diet (BD) based on AIN -93G formulation with some modification (Reeves et al.,1993) and water $a d$ libitum in the acclimatization period (one week). After this period, the animals were divided equally into 7 treatment groups of equal mean weights (6 rats/group) as follows :

- Group 1 fed on BD $^{1}$ (reference group).

- Group 2 fed on baby cereal formula (formula 1) as shown in Table (1), control group

- Group 3 fed on baby cereal formula supplemented with Bifidobacteriumbifidum (Bb) at concentration $8.95 \quad \log \mathrm{cfu} / \mathrm{g}$ (formula 2).

- Group 4 fed on baby cereal formula supplemented with dried powder of Jerusalem artichoke tubers at concentration $5 \%$ (formula3).

- Group 5 fed on baby cereal formula supplemented with dried powder of Jerusalem artichoke tubers at concentration $5 \%+\mathrm{Bb}$ at concentration $8.95 \mathrm{log} \mathrm{cfu} / \mathrm{g}$ (formula 4).

- Group 6 fed on baby cereal formula supplemented with dried powder of Jerusalem artichoke tubers at concentration $10 \%$ (formula 5).

- Group 7 fed on baby cereal formula supplemented with dried powder of

Jerusalem artichoke tubers at concentration $10 \%+\mathrm{Bb}$ at concentration $8.95 \mathrm{log} \mathrm{cfu} / \mathrm{g}$ (formula 6).

${ }^{1}$ BD ingredients (g/100 g diet) consist of : Casein 20 (13\% protein) ,corn oil 9,cellulose 5,mineral mix 3.5,vitamin mix 1 ,sucrose 10 ,L-cysteine 0.18 , choline bitartrate 0.25 corn starch 51 (based on AIN -93G formulation).
The experimental period continued for 5 weeks. During the first four weeks, water was allowed ad-libitum, the body weight was recorded weekly and the food intake was recorded each two days. At the fifth week, a controlled metabolic study was carried out. Through this period, daily food intake was recorded. At the same time, daily excretions of stool and urine were collected. The total urine volume was recorded at the end of the study. The stool and urine were frozen immediately after the daily collection.

At termination of the experiment, the diet of each group was removed $6 \mathrm{~h}$ before anethesing the rats. Blood samples were collected from the orbit ocular vein.The serum was separated by centrifugation at $4^{\circ} \mathrm{C}$ (3000 rpm for $\left.10 \mathrm{~min}\right)$ and stored frozen at $-20^{\circ} \mathrm{C}$ for subsequent chemical analyses. The caecum was separated immediately and weighed, its contents collected after cutting off the caecal wall and weighed. Weight of total caecum and its contents were calculated relative to body weight. The caecal contents were diluted with four times of deionized water and homogenized by homogenizer. The $\mathrm{pH}$ of homogenate was measured by $\mathrm{pH}$ meter. Right and left Femurs were dissected, cleaned, freed from the surrounding tissues and filled in physiological saline and stored at $-20^{\circ} \mathrm{C}$.

\subsubsection{Determination of serum and urine chemistry}

Serum and urine of the total calcium and phosphorus were estimated calorimetrically by the method given by Weatherburn et al. (1982) as cited in Linear Chemicals. Serum and urine magnesium were estimated according to the method of Bohuon et al. (1962) as cited in Quimica Clinica Aplicada.

\subsubsection{Determination of minerals in bones, diet and feces}

Dry femurs were ashed in muffle furnace at 600. The ash was dissolved in $\mathrm{HCl}(3.0 \mathrm{ml})$ then evaporated to about $1.0 \mathrm{ml}$ on a hot plate. After cooling, it was made up to $25 \mathrm{ml}$ with deionized water. Portions of the dry sample ( 0.35 of each diet or feces ) were ashed at $600^{\circ} \mathrm{C}$ for $10 \mathrm{~h}$ then dissolved in concentrated nitric acid $(3.0 \mathrm{ml})$ and hydrogen peroxide $(1.0 \mathrm{ml})$ at $130^{\circ} \mathrm{C}$ until discoloration. Final volume $(25 \mathrm{ml})$ was made by $3 \%$ nitric solution. The concentrations of each element in prepared samples of bone, feces and diets were measured by flame atomic absorption spectrophotometer AAS (Model3300, 
Perkin-Elmer, Beaconsfield, UK) according to the method of Robberecht et al.(1994).

Mineral apparent absorption, balance, retention and dietary mineral efficiency were calculated according to Scholz-Ahrens et al. (2002) using the following equations:

Mineral apperent absorption $\%$

$=\frac{(\text { Daily mineral intake }- \text { daily fecal }) \times 100}{x}$ Daily mineral intake

Mineral balance $=$ daily mineral intake $-($ fecal mineral + urinary mineral)

Mineral retention $\%=\frac{\text { mineral balance } \mathbf{x} 100}{\text { daily mineral intake }}$

Dietary mineral efficiency $\%=\frac{\text { mineral content } \mathrm{x} \mathbf{1 0 0}}{\text { total mineral intake }}$

\subsection{Statistical Analysis}

Data were presented as mean \pm S.E. and analyzed by one-way analysis of variance (ANOVA) and Duncan's test $(P \leq 0.05)$ were used to establish the significance of differences according to the method of Snedecor and Cochran (1989). The result was performed using the SPSS software version 19 windows program.

\section{RESULTS AND DISCUSSION}

\subsection{Chemical composition of baby cereals}

The chemical compositions of baby cereal prepared from different formulas were analyzed and the data showed in Table (2). From the data in the table, inulin content was $3.2 \%$ in F3 and F4, while $6.3 \%$ in F5 and F6. This result indicates that the concentration of inulin in Jerusalem artichoke was high (about $64 \%$ on dry matter) compared to other plants such as onion, leek, garlic and artichoke (Deleenheer, 1996). The other chemical composition carbohydrates, protein, fat, fiber, ash and moisture were slightly non- significant affected by adding Jerusalem artichoke in all formulas. The chemical composition of the formulas was agreed with the Egyptian infant food based from cereals standard 3284/2005.

\subsection{Storage stability of Bifidobacteria on baby cereals formulas}

The storage actual stability of the different formulas of baby cereals with bifidobacterium was studied for 6 months. The bifidobacterial count was $8.95(\log \mathrm{cfu} / \mathrm{g})$ at zero time and after 6 months, it ranged from 7.81-8.46 (log cfu/g). The results indicated that the bifidobacterial count was stable during storage for 6 months especially in the formula No. 6 which contained $10 \%$ of Jerusalem artichoke. These results are in agreement with Gibson and Wang (1994) who stated that in pure cultures; most species of bifidobacteria are adept at the use of inulin-type fructans.

\subsection{Body weight gain and feed efficiency}

As shown in Table (3), supplementation of baby foods with bifidogenic Jerusalem artichoke (inulin) maintained the normal growth rate and feed efficiency as the control group or the reference group. The obtained results agree with the previous results who reported that no significant differences were found neither in the daily feed intake nor in the body weight gain between the control group and those fed on diets contained inulin or resistant starch as reported by Younes et al. (2001).

\subsection{Fecal bulk and caecal weight and $\mathrm{pH}$}

As shown in Table (4), the fecal excretion was significantly increased in all the treated groups except group 3 supplemented with bifidobacteria only in comparison to the control group. The highest value (9.26 g) was recorded for group 7 that consumed formula containing

Table (2): Chemical composition of different formulas of baby cereals per $100 \mathrm{~g}$ on dry weight basis.

\begin{tabular}{|c|c|c|c|c|c|c|}
\hline Material (\%) & F1 & F2 & F3 & F4 & F5 & F6 \\
\hline Moisture & 5 & 4.8 & 5 & 4.8 & 4 & 4.8 \\
\hline Dry matter & 95 & 95.2 & 95 & 95.2 & 96 & 95.2 \\
\hline Protein & 13.0 & 12.92 & 12.90 & 12.91 & 12.80 & 12.82 \\
\hline Fats & 9 & 9.0 & 8.98 & 8.97 & 8.98 & 8.96 \\
\hline Ash & 4.5 & 4.5 & 4.7 & 4.7 & 5.0 & 5.0 \\
\hline Crude fiber & 1.5 & 1.48 & 1.65 & 1.66 & 1.8 & 1.79 \\
\hline Total carbohydrates* & 72 & 72.1 & 71.77 & 71.76 & 71.42 & 71.43 \\
\hline Inulin & - & - & 3.2 & 3.2 & 6.3 & 6.3 \\
\hline \multicolumn{7}{|c|}{$\begin{array}{lc}\text { F1: control baby food formula } & \text { F2:control baby food formula }+\mathrm{Bb} \\
\text { F3:control baby food formula }+5 \% \mathrm{Ja} . & \text { F4:control baby food formula+Bb+5\%Ja. } \\
\text { F5:control baby food formula }+10 \% \mathrm{Ja} \text {. } & \text { F6:control baby food formula }+\mathrm{Bb}+10 \% \mathrm{Ja} . \\
\text { *Total carbohydrates calculated by difference according to the following equation: }\end{array}$} \\
\hline
\end{tabular}


Table (3): The effect of different baby cereal formulas on body weight gain, feed intake and feed efficiency.

\begin{tabular}{|c|c|c|c|c|}
\hline $\begin{array}{l}\text { Treated } \\
\text { groups }\end{array}$ & $\begin{array}{l}\text { B.W gain } \\
\text { (g) }\end{array}$ & $\begin{array}{c}\text { Daily B.W gain } \\
\text { (g/d) }\end{array}$ & $\begin{array}{l}\text { Daily feed Intake } \\
(\mathrm{g} / \mathrm{d})\end{array}$ & $\begin{array}{c}\text { Feed Efficiency } \\
(\mathrm{g} / \mathrm{g})\end{array}$ \\
\hline G1 & $41.33 \mathrm{c} \pm 0.67$ & $1.47 \mathrm{~b} \pm 0.02$ & $11.83 a \pm 0.03$ & 0.12 bc \pm .003 \\
\hline G2 & 43.00 bc \pm 1.73 & $1.53 \mathrm{ab} \pm 0.06$ & $12.83 \mathrm{a} \pm 0.01$ & 0.12 abc \pm 0.005 \\
\hline G3 & $40.00 \mathrm{c} \pm 1.15$ & 1.42 b \pm 0.04 & 12.85 a \pm 0.03 & $0.11 \mathrm{c} \pm 0.003$ \\
\hline G4 & $47.33 a b \pm 1.20$ & $1.68 \mathrm{a} \pm 0.04$ & $12.83 a \pm 0.01$ & 0.13 ab \pm 0.005 \\
\hline G5 & $47.33 \mathrm{ab} \pm 1.76$ & $1.68 a \pm 0.06$ & $12.83 \mathrm{a} \pm 0.01$ & 0.13 ab \pm 0.006 \\
\hline G6 & $48.66 a \pm 0.88$ & $1.73 \mathrm{a} \pm 0.03$ & 12.84 a \pm 0.01 & 0.13 a \pm 0.003 \\
\hline G7 & 45.33 abc \pm 3.17 & $1.61 \mathrm{ab} \pm 0.11$ & 12.84 a \pm 0.01 & 0.12 abc \pm 0.008 \\
\hline
\end{tabular}

Different letters in the same column denote statistical significance $(\mathbf{P}<0.05)$.

Table(4): The effect of different baby cereal formulas on fecal bulk and weight $\%$ and $\mathrm{pH}$ of cecum.

\begin{tabular}{|c|c|c|c|c|}
\hline $\begin{array}{c}\text { Treated } \\
\text { groups }\end{array}$ & $\begin{array}{c}\text { Fresh Fecal Weight } \\
(\mathrm{g})\end{array}$ & $\begin{array}{c}\text { Fecal Moisture } \\
(\%)\end{array}$ & $\begin{array}{c}\text { Total caecal Weight } \\
\%\end{array}$ & Caecal pH \\
\hline G1 & $8.53 \mathrm{ab} \pm 0.03$ & $26.00 \mathrm{~cd} \pm 1.00$ & 0.35 e \pm 0.01 & $7.13 \mathrm{a} \pm 0.12$ \\
\hline G2 & $4.56 \mathrm{~d} \pm 0.49$ & $23.83 \mathrm{~cd} \pm 1.64$ & $0.62 \mathrm{~d} \pm 0.01$ & $6.93 \mathrm{ab} \pm 0.08$ \\
\hline G3 & $3.66 \mathrm{~d} \pm 0.27$ & $20.40 \mathrm{~d} \pm 2.13$ & $0.78 d \pm 0.08$ & 6.80 bc \pm 0.17 \\
\hline G4 & $6.13 \mathrm{c} \pm 0.12$ & 28.83 bc \pm 2.80 & $0.98 b \pm 0.03$ & $6.56 \mathrm{~cd} \pm 0.03$ \\
\hline G5 & $7.73 \mathrm{~b} \pm 0.66$ & 28.00 bc \pm 3.60 & $0.95 b \pm 0.08$ & 6.30 de \pm 0.05 \\
\hline G6 & $9.10 \mathrm{a} \pm 0.20$ & $35.00 \mathrm{~b} \pm 2.51$ & $1.0 \mathrm{a} \pm 0.08$ & 6.10 ef \pm 0.05 \\
\hline G7 & $9.26 \mathrm{a} \pm 0.26$ & $47.66 \mathrm{a} \pm 1.33$ & $1.36 \mathrm{a} \pm 0.01$ & $5.83 f \pm 0.03$ \\
\hline
\end{tabular}

Different letters in the same column denote statistical significance $(\mathrm{P}<0.05)$.

bifidobacteria $+10 \%$ Ja. Fecal moisture percent was significantly increased in groups 6 and7 as compared with the control group. The present results are in a good agreement with earlier reports which confirmed that non-digestible carbohydrates increased the fecal bulking (wet weight and moisture percentage of feces) due to increase in the biomass (Pascoal et al., 2005).

The results of the total caecal weight \%, (relative to body weight) and caecal $\mathrm{pH}$ are shown in Table (4). It was clearly showed that the consumption of the formula were containing Ja $5 \%$ or $10 \%$ was associated with a significant increase in the total caecal weight. Moreover, this increase was obvious when probiotic bacteria were combined with $10 \% \mathrm{Ja}$ in group 7 . In contrast, the caecal $\mathrm{pH}$ tended to decrease significantly when the weaning formula was supplemented with Ja and bifidobacteria. Group 7 recorded the lowest value in caecal $\mathrm{pH}$. This result suggests that the increase in caecal weight was due to wall thickening and that the colonization of the caecal with bifidobacteria was successful in response to long term feeding of bifidogenic inulin. Our results agree with the previous studies which demonstrated that nonmilk oligosaccharides from inulin are able to mimic the prebiotic effects of breast milk by significantly increasing Bifidobacterium spp., by increasing the production of short chain fatty acids (SCFA) and lowering caecal $\mathrm{pH}$ (Kim et al., 2007).

\subsection{Absorption, balance and retention of} calcium

As shown from the obtained data in Table (5), in the case of serum $\mathrm{Ca}$, feeding on baby formulas supplemented with $10 \% \mathrm{Ja}$ without or with probiotic recorded the highest mean values (groups 6 and 7) and were significantly higher than the control group. Fecal $\mathrm{Ca}$ excretion was decreased significantly in rats fed on formulas supplemented with bifidobacteria and / or Jerusalem artichoke except group 4 with the lowest value recorded in group 7 relative to control formula. Also, group 7 showed a significant increment in apparent $\mathrm{Ca}$ absorption percentage. Concerning the urinary $\mathrm{Ca}$ excretion, no statistical differences were found in the groups 5 and 6, but groups 3, 4 and 7 showed significant differences when compared with the control group (G2). There was a marked increment of $\mathrm{Ca}$ balance and retention $\%$ in the treatments of groups 5, 6 and 7 which recorded the highest mean value. It is suggested that the diet supplemented with prebiotic and / or probiotic may be increased the absorption and retention of $\mathrm{Ca}$ especially at high dose of prebiotic (100 $\mathrm{g} / \mathrm{kg}$ diet) and combined with Bifidobacteria. The trend observed was consistent to the results of Gopal et al., (2003) 
Table (5): The effect of baby cereal formulas on absorption, balance and retention of calcium.

\begin{tabular}{|c|c|c|c|c|c|c|c|c|}
\hline $\begin{array}{l}\text { Treated } \\
\text { groups }\end{array}$ & $\begin{array}{c}\text { Serum } \\
\text { Ca } \\
(\mathrm{mg} / \mathrm{dl})\end{array}$ & $\begin{array}{c}\text { Ca Intake } \\
(\mathrm{mg} / \mathrm{d})\end{array}$ & $\begin{array}{c}\text { Fecal } \\
\text { Ca } \\
(\mathrm{mg} / \mathrm{d})\end{array}$ & $\begin{array}{l}\text { Apparent } \\
\text { Ca } \\
\text { Absorption } \\
\text { (mg/d) }\end{array}$ & $\begin{array}{c}\text { Apparent } \\
\text { Ca } \\
\text { Absorption } \\
(\%)\end{array}$ & $\begin{array}{c}\text { Urinary } \\
\text { Ca } \\
(\mathrm{mg} / \mathrm{d})\end{array}$ & $\begin{array}{c}\text { Ca } \\
\text { balance } \\
(\mathrm{mg} / \mathrm{d})\end{array}$ & $\begin{array}{c}\mathrm{Ca} \\
\text { retention } \\
\%\end{array}$ \\
\hline G1 & $\begin{array}{c}7.66 \text { b } \\
\pm 0.37\end{array}$ & $\begin{array}{c}205.00 \mathrm{c} \\
\pm 2.88\end{array}$ & $\begin{array}{c}110.00 \mathrm{~b} \\
\pm 2.86\end{array}$ & $\begin{array}{c}95.00 \mathrm{~cd} \\
\pm 2.88\end{array}$ & $\begin{array}{c}46.34 \mathrm{~b} \\
\pm 3.46\end{array}$ & $\begin{array}{c}1.40 \mathrm{~cd} \\
\pm 0.34\end{array}$ & $\begin{array}{c}93.60 \mathrm{~cd} \\
\pm 3.75\end{array}$ & $\begin{array}{c}45.66 \mathrm{~b} \\
\pm 3.17\end{array}$ \\
\hline G2 & $\begin{array}{l}7.61 \mathrm{~b} \\
\pm 0.25\end{array}$ & $\begin{array}{c}\text { 214.00 abc } \\
\pm 3.46\end{array}$ & $\begin{array}{c}125.00 \mathrm{a} \\
\pm 1.73\end{array}$ & $\begin{array}{c}89.00 \mathrm{~d} \\
\pm 3.46\end{array}$ & $\begin{array}{c}41.59 \mathrm{~b} \\
\pm 4.04\end{array}$ & $\begin{array}{l}2.20 \mathrm{a} \\
\pm 0.23\end{array}$ & $\begin{array}{c}86.80 \mathrm{~d} \\
\pm 2.60\end{array}$ & $\begin{array}{c}40.56 \mathrm{~b} \\
\pm 2.88\end{array}$ \\
\hline G 3 & $\begin{array}{c}8.37 \mathrm{ab} \\
\pm 0.22\end{array}$ & $\begin{array}{c}206.66 \text { bc } \\
\pm 1.66\end{array}$ & $\begin{array}{c}105.00 \mathrm{~b} \\
\pm 2.88\end{array}$ & $\begin{array}{c}101.00 \text { bc } \\
\pm 3.46\end{array}$ & $\begin{array}{c}49.03 \mathrm{~b} \\
\pm 1.85\end{array}$ & $\begin{array}{r}0.92 \mathrm{~d} \\
\pm 0.078\end{array}$ & $\begin{array}{c}100.74 \text { bc } \\
\pm 2.88\end{array}$ & $\begin{array}{c}48 . .75 b \\
\pm 3.45\end{array}$ \\
\hline G 4 & $\begin{array}{c}8.25 \mathrm{ab} \\
\pm 0.25 \\
\end{array}$ & $\begin{array}{c}208.33 \text { abc } \\
\pm 2.88 \\
\end{array}$ & $\begin{array}{c}120.00 \mathrm{a} \\
\pm 2.88 \\
\end{array}$ & $\begin{array}{c}88.33 \mathrm{~d} \\
\pm 2.18 \\
\end{array}$ & $\begin{array}{c}42.40 \mathrm{~b} \\
\pm 2.88 \\
\end{array}$ & $\begin{array}{l}1.27 \mathrm{~d} \\
\pm 0.15 \\
\end{array}$ & $\begin{array}{c}86.73 \mathrm{~d} \\
\pm 3.46 \\
\end{array}$ & $\begin{array}{c}41.70 \mathrm{~b} \\
\pm 2.88 \\
\end{array}$ \\
\hline G 5 & $\begin{array}{c}8.16 \text { ab } \\
\pm 0.25 \\
\end{array}$ & $\begin{array}{c}212.00 \text { abc } \\
\pm 2.88\end{array}$ & $\begin{array}{c}106.33 \mathrm{~b} \\
\pm 3.48 \\
\end{array}$ & $\begin{array}{c}105.67 \mathrm{~b} \\
\pm 4.48 \\
\end{array}$ & $\begin{array}{c}49.84 \mathrm{~b} \\
\pm 3.46 \\
\end{array}$ & $\begin{array}{c}1.50 \text { bed } \\
\pm 0.28\end{array}$ & $\begin{array}{c}104.17 \text { b } \\
\pm 3.46\end{array}$ & $\begin{array}{c}49.14 \mathrm{~b} \\
\pm 2.88 \\
\end{array}$ \\
\hline G 6 & $\begin{array}{c}8.56 \text { a } \\
\pm 0.20 \\
\end{array}$ & $\begin{array}{c}215.00 \mathrm{ab} \\
\pm 2.88\end{array}$ & $\begin{array}{c}105.00 \mathrm{~b} \\
\pm 2.85\end{array}$ & $\begin{array}{c}110.00 \mathrm{~b} \\
\pm 2.88\end{array}$ & $\begin{array}{c}51.16 \text { ab } \\
\pm 3.48\end{array}$ & $\begin{array}{c}2.10 \mathrm{ab} \\
\pm 0.28\end{array}$ & $\begin{array}{c}107.90 \mathrm{~b} \\
\pm 2.88\end{array}$ & $\begin{array}{c}50.19 \text { b } \\
\pm 2.74\end{array}$ \\
\hline G 7 & $\begin{array}{l}8.77 \text { a } \\
\pm 0.15 \\
\end{array}$ & $\begin{array}{c}216.00 \mathrm{a} \\
\pm 2.30 \\
\end{array}$ & $\begin{array}{c}85.00 \text { c } \\
\pm 2.88\end{array}$ & $\begin{array}{c}131.00 \text { a } \\
\pm 2.88\end{array}$ & $\begin{array}{c}60.65 \text { a } \\
\pm 2.88 \\
\end{array}$ & $\begin{array}{l}0.95 \mathrm{~d} \\
\pm 0.05 \\
\end{array}$ & $\begin{array}{c}130.05 \text { a } \\
\pm 2.88\end{array}$ & $\begin{array}{c}60.21 \text { a } \\
\pm 2.88 \\
\end{array}$ \\
\hline
\end{tabular}

Different letters in the same column denote statistical significance $(P<0.05)$.

who suggested that synbiotic stimulated the fecal bacteria counts of Lactobacilli and Bifidobacteria in human subject, but little effect was seen when only the probiotic (Bifidobacteriumlactis HN019) or the prebiotic (galacto-oligosacchrides) was given. The explanation contributed to the enhanced mineral absorption is the trophic effect of prebiotics on the gut (cell growth and functional enhancement of the absorptive area) (Raschka and Daniel, 2005 ).

\subsection{Absorption, balance and retention of} magnesium

As shown in Table (6), no significant differences were observed in serum levels of $\mathrm{Mg}$ between the treated groups and the control group. Supplementation of baby food with bifidobacteria and/or Jerusalem artichoke as a source of inulin did not affect the daily $\mathrm{Mg}$ intake, while fecal $\mathrm{Mg}$ showed a significant decreasing compared to the control (G2) or the reference group $(\mathrm{G} 1)$. This was accompanied with significant increasing in apparent $\mathrm{Mg}$ absorption values (absolute or percent) of the treated groups. Although the treated groups (4, 5, 6 and7) recorded higher values of urinary $\mathrm{Mg}$ excretion relative to the control, but $\mathrm{Mg}$ balance and retention showed marked improvement in all treated groups with the highest values in rats supplemented with prebiotics and probiotics (groups 5 and 7). The present data were confirmed by Demigné et al. (2008) who reported that, in rat model, both native inulin and reformulated inulin exerted similar effects as to caecal fermentation by the production of short-chain fatty acids (SCFA), especially butyric acid and stimulation of $\mathrm{Ca}$ and $\mathrm{Mg}$ digestive absorption and affect the bone mineral density.

3.7.Absorption, balance and retention of phosphorus

The data presented in Table (7) illustrated that group 7 only showed the pronounced increment in serum P. Supplementation the baby formula with prebiotic and/or probiotic did not affect significantly the fecal $\mathrm{P}$ excretion values and apparent $\mathrm{P}$ absorption percentage. In contrary, urinary excretion of $\mathrm{P}$ decreased significantly in all treatment groups except group 4 as compared to rats fed on the control formula. Feeding on baby formulas with bifidobacteria and/or inulin caused increment in $\mathrm{P}$ balance and retention with higher value in group 7. These data are in line with those given by Rideout and Fan (2004) who reported that in growing pigs, inulin had no effect on $\mathrm{P}$ absorption but reduced urinary $\mathrm{P}$ excretion. Another study on rats revealed significantly higher $\mathrm{P}$ retention at the medium dose of oligofructose $(50 \mathrm{~g} / \mathrm{kg})$ after 8 weeks and at the high dose oligofructose $(100 \mathrm{~g} / \mathrm{kg})$ after 4 weeks. This effect was mediated by a reduction of urinary $\mathrm{P}$ excretion (Scholz-Ahrens and Schrezenmeir, 2007).

\subsection{Mineral contents in femurs}

As shown in Table (8), calcium and phosphorus contents in femurs showed significant increases in the treated groups especially group 7 for $\mathrm{Ca}$ and groups 5 and 7 for $P$ relative to the control group or the reference 
Table (6): The effect of different weaning cereal foods on absorption, balance and retention of magnesium.

\begin{tabular}{|c|c|c|c|c|c|c|c|c|}
\hline $\begin{array}{c}\text { Treated } \\
\text { groups }\end{array}$ & $\begin{array}{c}\text { Serum } \\
\mathbf{M g} \\
\mathrm{mg} / \mathrm{dl}\end{array}$ & $\begin{array}{c}\text { Mg } \\
\text { Intake } \\
(\mathrm{mg} / \mathrm{d})\end{array}$ & $\begin{array}{c}\text { Fecal } \\
\text { Mg } \\
(\mathbf{m g} / \mathbf{d})\end{array}$ & $\begin{array}{c}\text { Apparent Mg } \\
\text { Absorption } \\
(\mathbf{m g} / \mathbf{d})\end{array}$ & $\begin{array}{c}\text { Apparent Mg } \\
\text { Absorption } \\
(\%)\end{array}$ & $\begin{array}{c}\text { Urinary } \\
\mathbf{M g} \\
(\mathbf{m g} / \mathbf{d}) \\
\end{array}$ & $\begin{array}{c}\text { Mg } \\
\text { balance } \\
(\mathbf{m g} / \mathbf{d})\end{array}$ & $\begin{array}{c}\text { Mg } \\
\text { retention } \\
\% \\
\end{array}$ \\
\hline G1 & $\begin{array}{l}2.69 \mathrm{a} \\
\pm 0.22\end{array}$ & $\begin{array}{c}10.26 \mathrm{a} \\
\pm 0.80\end{array}$ & $\begin{array}{l}5.93 \mathrm{~b} \\
\pm 0.41\end{array}$ & $\begin{array}{l}4.33 \mathrm{~b} \\
\pm 0.69\end{array}$ & $\begin{array}{c}42.20 \mathrm{~d} \\
\pm 1.16\end{array}$ & $\begin{array}{c}0.15 \mathrm{c} \\
\pm 0.015\end{array}$ & $\begin{array}{c}4.18 \text { bc } \\
\pm 0.61\end{array}$ & $\begin{array}{c}40.74 \mathrm{e} \\
\pm 1.43 \\
\end{array}$ \\
\hline G2 & $\begin{array}{r}2.70 \mathrm{a} \\
\pm 0.04 \\
\end{array}$ & $\begin{array}{c}10.60 \mathrm{a} \\
\pm 0.37\end{array}$ & $\begin{array}{l}6.98 \mathrm{a} \\
\pm 0.75 \\
\end{array}$ & $\begin{array}{l}3.62 \mathrm{~b} \\
\pm 0.37 \\
\end{array}$ & $\begin{array}{c}34.15 \mathrm{e} \\
\pm 1.73 \\
\end{array}$ & $\begin{array}{c}0.41 \text { bc } \\
\pm 0.07 \\
\end{array}$ & $\begin{array}{l}3.21 \mathrm{c} \\
\pm 0.15 \\
\end{array}$ & $\begin{array}{c}30.28 \mathrm{f} \\
\pm 1.45 \\
\end{array}$ \\
\hline G3 & $\begin{array}{r}2.76 \mathrm{a} \\
\pm 0.04 \\
\end{array}$ & $\begin{array}{c}11.20 \mathrm{a} \\
\pm 0.60\end{array}$ & $\begin{array}{l}4.15 \mathrm{c} \\
\pm 0.51 \\
\end{array}$ & $\begin{array}{l}7.05 \mathrm{a} \\
\pm 0.86 \\
\end{array}$ & $\begin{array}{c}62.95 \mathrm{c} \\
\pm 4.05 \\
\end{array}$ & $\begin{array}{l}0.19 \mathrm{c} \\
\pm 0.01 \\
\end{array}$ & $\begin{array}{r}6.86 \mathrm{a} \\
\pm 0.92 \\
\end{array}$ & $\begin{array}{c}61.25 \mathrm{~b} \\
\pm 1.45 \\
\end{array}$ \\
\hline G4 & $\begin{array}{c}2.55 \mathrm{ab} \\
\pm 0.02\end{array}$ & $\begin{array}{c}11.66 \mathrm{a} \\
\pm 1.06\end{array}$ & $\begin{array}{l}4.12 \mathrm{c} \\
\pm 0.23\end{array}$ & $\begin{array}{l}7.54 \mathrm{a} \\
\pm 0.83\end{array}$ & $\begin{array}{c}64.67 \mathrm{c} \\
\pm 1.27\end{array}$ & $\begin{array}{r}1.43 \mathrm{a} \\
\pm 0.14 \\
\end{array}$ & $\begin{array}{c}6.11 a b \\
\pm 0.34 \\
\end{array}$ & $\begin{array}{c}52.40 \mathrm{~d} \\
\pm 2.00\end{array}$ \\
\hline G5 & $\begin{array}{l}2.58 \mathrm{a} \\
\pm 0.19 \\
\end{array}$ & $\begin{array}{c}12.33 \mathrm{a} \\
\pm 0.88\end{array}$ & $\begin{array}{l}3.50 \mathrm{~d} \\
\pm 0.43\end{array}$ & $\begin{array}{l}8.83 \mathrm{a} \\
\pm 1.17 \\
\end{array}$ & $\begin{array}{c}71.61 \mathrm{ab} \\
\pm 1.27 \\
\end{array}$ & $\begin{array}{l}1.10 \mathrm{a} \\
\pm 0.28 \\
\end{array}$ & $\begin{array}{r}7.73 \mathrm{a} \\
\pm 0.82 \\
\end{array}$ & $\begin{array}{c}62.69 \mathrm{~b} \\
\pm 0.90\end{array}$ \\
\hline G6 & $\begin{array}{c}2.53 \mathrm{ab} \\
\pm 0.05\end{array}$ & $\begin{array}{c}12.46 \mathrm{a} \\
\pm 1.29\end{array}$ & $\begin{array}{l}4.22 \mathrm{c} \\
\pm 0.23\end{array}$ & $\begin{array}{l}8.24 \mathrm{a} \\
\pm 1.01 \\
\end{array}$ & $\begin{array}{c}66.13 \mathrm{bc} \\
\pm 1.07 \\
\end{array}$ & $\begin{array}{l}1.18 \text { a } \\
\pm 0.13 \\
\end{array}$ & $\begin{array}{r}7.06 \mathrm{a} \\
\pm 1.06 \\
\end{array}$ & $\begin{array}{c}56.66 \mathrm{c} \\
\pm 1.32 \\
\end{array}$ \\
\hline G7 & $\begin{array}{r}2.91 \mathrm{a} \\
\pm 0.06 \\
\end{array}$ & $\begin{array}{c}11.90 \mathrm{a} \\
\pm 0.49\end{array}$ & $\begin{array}{l}3.13 \mathrm{~d} \\
\pm 0.45 \\
\end{array}$ & $\begin{array}{l}8.77 \mathrm{a} \\
\pm 0.69 \\
\end{array}$ & $\begin{array}{c}73.70 \mathrm{a} \\
\pm 1.45 \\
\end{array}$ & $\begin{array}{l}0.65 \text { b } \\
\pm 0.11 \\
\end{array}$ & $\begin{array}{r}8.12 \text { a } \\
\pm 0.18 \\
\end{array}$ & $\begin{array}{c}68.24 \text { a } \\
\pm 0.96 \\
\end{array}$ \\
\hline
\end{tabular}

Different letters in the same column denote statistical significance $(\mathbf{P}<0.05)$.

Table (7): the effect of different baby cereal formulas on absorption, balance and retention of phosphorus.

\begin{tabular}{|c|c|c|c|c|c|c|c|c|}
\hline $\begin{array}{c}\text { Treated } \\
\text { groups }\end{array}$ & $\begin{array}{c}\text { serum P } \\
(\mathrm{mg} / \mathrm{dl})\end{array}$ & $\begin{array}{c}\text { P Intake } \\
(\mathrm{mg} / \mathrm{d})\end{array}$ & $\begin{array}{c}\text { Fecal P P } \\
(\mathrm{mg} / \mathrm{d})\end{array}$ & $\begin{array}{c}\text { Apparent P } \\
\text { Absorption } \\
(\mathbf{m g} / \mathbf{d})\end{array}$ & $\begin{array}{c}\text { Apparent P } \\
\text { Absorption } \\
(\%)\end{array}$ & $\begin{array}{l}\text { Urinary } \\
P(\mathrm{mg} / \mathrm{d})\end{array}$ & $\begin{array}{c}P \text { balance } \\
(\mathrm{mg} / \mathrm{d})\end{array}$ & $\begin{array}{c}\mathbf{P} \\
\text { retention } \\
\%\end{array}$ \\
\hline G1 & $\begin{array}{l}8.69 \mathrm{~d} \\
\pm 0.17\end{array}$ & $\begin{array}{c}91.66 \mathrm{c} \\
\pm 4.41\end{array}$ & $\begin{array}{c}40.00 \text { a } \\
\pm 2.88\end{array}$ & $\begin{array}{c}51.66 \mathrm{~d} \\
\pm 2.02\end{array}$ & $\begin{array}{c}56.36 \mathrm{~b} \\
\pm 0.88\end{array}$ & $\begin{array}{l}0.70 \mathrm{~d} \\
\pm 0.17\end{array}$ & $\begin{array}{c}51.96 \mathrm{e} \\
\pm 3.78 \\
\end{array}$ & $\begin{array}{c}55.60 \mathrm{~d} \\
\pm 0.88\end{array}$ \\
\hline G2 & $\begin{array}{c}9.81 \text { bc } \\
\pm 0.46 \\
\end{array}$ & $\begin{array}{c}98.33 \text { bc } \\
\pm 1.66 \\
\end{array}$ & $\begin{array}{c}28.66 \text { bc } \\
\pm 0.66 \\
\end{array}$ & $\begin{array}{c}69.67 \mathrm{~d} \\
\pm 1.20 \\
\end{array}$ & $\begin{array}{c}71.85 \text { a } \\
\pm 3.78 \\
\end{array}$ & & $\begin{array}{c}62.81 d \\
\pm 1.76 \\
\end{array}$ & $\begin{array}{c}63.88 \mathrm{c} \\
\pm 2.31 \\
\end{array}$ \\
\hline G3 & $\begin{array}{l}9.20 \mathrm{c} \\
\pm 0.05\end{array}$ & $\begin{array}{c}110.33 \mathrm{ab} \\
\pm 2.88\end{array}$ & $\begin{array}{c}25.00 \text { c } \\
\pm 1.15\end{array}$ & $\begin{array}{c}85.33 \text { ab } \\
\pm 2.90\end{array}$ & $\begin{array}{c}77.34 \mathrm{a} \\
\pm 1.45 \\
\end{array}$ & $\begin{array}{l}4.36 \mathrm{c} \\
\pm 0.16\end{array}$ & $\begin{array}{c}80.97 a b \\
\pm 1.20\end{array}$ & $\begin{array}{c}73.39 \mathrm{ab} \\
\pm 2.40\end{array}$ \\
\hline G4 & $\begin{array}{l}9.11 \mathrm{c} \\
\pm 0.26 \\
\end{array}$ & $\begin{array}{c}112.00 \mathrm{a} \\
\pm 2.31\end{array}$ & $\begin{array}{c}31.33 \text { b } \\
\pm 0.66 \\
\end{array}$ & $\begin{array}{c}\text { 80.67abc } \\
\pm 1.20 \\
\end{array}$ & $\begin{array}{c}72.03 \mathrm{a} \\
\pm 1.15 \\
\end{array}$ & $\begin{array}{l}8.00 \text { a } \\
\pm 0.42 \\
\end{array}$ & $\begin{array}{c}72.67 \mathrm{bc} \\
\pm 1.20 \\
\end{array}$ & $\begin{array}{c}64.88 \mathrm{c} \\
\pm 1.15\end{array}$ \\
\hline G5 & $\begin{array}{c}9.61 \mathrm{bc} \\
\pm 0.22 \\
\end{array}$ & $\begin{array}{c}105.66 \mathrm{ab} \\
\pm 6.88 \\
\end{array}$ & $\begin{array}{c}\mathbf{3 1 . 0 0} \mathrm{b} \\
\pm \mathbf{3 . 0 5} \\
\end{array}$ & $\begin{array}{c}74.66 \mathrm{~cd} \\
\pm 2.88 \\
\end{array}$ & $\begin{array}{c}70.66 \mathrm{a} \\
\pm 1.15 \\
\end{array}$ & $\begin{array}{l}3.60 \mathrm{c} \\
\pm 0.30 \\
\end{array}$ & $\begin{array}{c}71.06 \mathrm{~cd} \\
\pm 4.33 \\
\end{array}$ & $\begin{array}{c}67.25 \text { bc } \\
\pm 1.52 \\
\end{array}$ \\
\hline G6 & $\begin{array}{c}10.08 \text { b } \\
\pm 0.13 \\
\end{array}$ & $\begin{array}{c}110.00 \mathrm{ab} \\
\pm 2.88\end{array}$ & $\begin{array}{c}31.33 \mathrm{~b} \\
\pm 1.33 \\
\end{array}$ & $\begin{array}{c}78.67 \mathrm{bc} \\
\pm 2.90 \\
\end{array}$ & $\begin{array}{c}71.52 \mathrm{a} \\
\pm 4.16\end{array}$ & $\begin{array}{l}4.33 \mathrm{c} \\
\pm 0.88\end{array}$ & $\begin{array}{c}74.34 \text { bc } \\
\pm 3.17 \\
\end{array}$ & $\begin{array}{c}67.58 \text { bc } \\
\pm 2.31\end{array}$ \\
\hline G7 & $\begin{array}{c}11.47 \text { a } \\
\pm 0.78 \\
\end{array}$ & $\begin{array}{c}112.00 \mathrm{a} \\
\pm 2.88 \\
\end{array}$ & $\begin{array}{c}23.33 \text { c } \\
\pm 1.66 \\
\end{array}$ & $\begin{array}{c}88.67 \text { a } \\
\pm 3.75 \\
\end{array}$ & $\begin{array}{c}79.17 \text { a } \\
\pm 2.88 \\
\end{array}$ & $\begin{array}{l}2.66 \mathrm{c} \\
\pm 0.33 \\
\end{array}$ & $\begin{array}{c}86.01 \text { a } \\
\pm 2.88 \\
\end{array}$ & $\begin{array}{c}76.79 \mathrm{a} \\
\pm 2.88 \\
\end{array}$ \\
\hline
\end{tabular}

Different letters in the same column denote statistical significance $(\mathbf{P}<0.05)$.

Table (8): The effect of baby formulas on, Ca, Mg and P content in femurs and dietary mineral efficiency percent.

\begin{tabular}{|c|c|c|c|c|c|c|}
\hline $\begin{array}{r}\text { Treated } \\
\text { groups }\end{array}$ & $\begin{array}{c}\mathbf{C a} \\
(\mathrm{mg} / \mathrm{f})\end{array}$ & $\begin{array}{c}\mathrm{Mg} \\
(\mathrm{mg} / \mathrm{f})\end{array}$ & $\begin{array}{c}\mathbf{P} \\
(\mathbf{m g} / \mathbf{f})\end{array}$ & $\begin{array}{l}\text { Dietary Ca } \\
\text { efficiency \% }\end{array}$ & $\begin{array}{l}\text { Dietary Mg } \\
\text { efficiency \% }\end{array}$ & $\begin{array}{l}\text { Dietary } \mathbf{P} \\
\text { efficiency } \%\end{array}$ \\
\hline G1 & $\begin{array}{c}184.33 \mathrm{c} \\
\pm 1.85\end{array}$ & $\begin{array}{l}3.57 \mathrm{e} \\
\pm 0.01\end{array}$ & $\begin{array}{c}37.66 \mathrm{cb} \\
\pm 0.33\end{array}$ & $\begin{array}{l}3.21 \mathrm{c} \\
\pm 0.01\end{array}$ & $\begin{array}{l}1.24 \mathrm{e} \\
\pm 0.02\end{array}$ & $\begin{array}{r}1.47 \mathrm{c} \\
\pm 0.01 \\
\end{array}$ \\
\hline G2 & $\begin{array}{c}181.33 \mathrm{c} \\
\pm 1.66 \\
\end{array}$ & $\begin{array}{l}4.04 d \\
\pm 0.15\end{array}$ & $\begin{array}{l}35.33 \mathrm{c} \\
\pm 2.33\end{array}$ & $\begin{array}{l}3.03 \mathrm{~d} \\
\pm 0.01\end{array}$ & $\begin{array}{l}1.36 \mathrm{~cd} \\
\pm 0.003\end{array}$ & $\begin{array}{c}1.28 \mathrm{e} \\
\pm 0.003 \\
\end{array}$ \\
\hline G3 & $\begin{array}{c}200.00 \mathrm{~b} \\
\pm 3.05 \\
\end{array}$ & $\begin{array}{r}4.09 \mathrm{~d} \\
\pm 0.098 \\
\end{array}$ & $\begin{array}{c}40.33 \mathrm{~b} \\
\pm 0.88 \\
\end{array}$ & $\begin{array}{l}3.46 b \\
\pm 0.01 \\
\end{array}$ & $\begin{array}{r}1.30 \mathrm{~d} \\
\pm 0.003 \\
\end{array}$ & $\begin{array}{c}1.31 d \\
\pm 0.005 \\
\end{array}$ \\
\hline G4 & $\begin{array}{c}204.66 \mathrm{ab} \\
\pm 6.96\end{array}$ & $\begin{array}{l}4.62 \mathrm{c} \\
\pm 0.30\end{array}$ & $\begin{array}{c}41.33 \mathrm{~b} \\
\pm 1.45\end{array}$ & $\begin{array}{l}3.51 \mathrm{~b} \\
\pm 0.01\end{array}$ & $\begin{array}{l}1.42 \mathrm{~b} \\
\pm 0.005\end{array}$ & $\begin{array}{l}1.32 \mathrm{~d} \\
\pm 0.01\end{array}$ \\
\hline G5 & $\begin{array}{c}205.33 \mathrm{ab} \\
\pm 0.88 \\
\end{array}$ & $\begin{array}{c}4.95 \mathrm{ab} \\
\pm 0.16\end{array}$ & $\begin{array}{c}49.33 \mathrm{a} \\
\pm 1.33\end{array}$ & $\begin{array}{l}3.46 \mathrm{~b} \\
\pm 0.01 \\
\end{array}$ & $\begin{array}{c}1.43 b \\
\pm 0.005 \\
\end{array}$ & $\begin{array}{c}1.67 a \\
\pm 0.003 \\
\end{array}$ \\
\hline G6 & $\begin{array}{c}207.66 \mathrm{ab} \\
\pm 3.66 \\
\end{array}$ & $\begin{array}{c}4.94 \mathrm{~b} \\
\pm 0.34 \\
\end{array}$ & $\begin{array}{c}41.66 \mathrm{~b} \\
\pm 1.20 \\
\end{array}$ & $\begin{array}{l}3.45 \mathrm{~b} \\
\pm 0.02 \\
\end{array}$ & $\begin{array}{c}1.42 b \\
\pm 0.005 \\
\end{array}$ & $\begin{array}{l}1.35 \mathrm{~d} \\
\pm 0.01 \\
\end{array}$ \\
\hline G7 & $\begin{array}{c}215.66 \mathrm{a} \\
\pm 6.09 \\
\end{array}$ & $\begin{array}{l}5.42 \text { a } \\
\pm 0.26 \\
\end{array}$ & $\begin{array}{c}\mathbf{5 0 . 0 0} \mathbf{a} \\
\mathbf{\pm 0 . 5 7}\end{array}$ & $\begin{array}{l}3.57 \text { a } \\
\pm 0.03 \\
\end{array}$ & $\begin{array}{c}1.63 \mathrm{a} \\
\pm 0.005\end{array}$ & $\begin{array}{r}1.60 \mathrm{ab} \\
\pm 0.003 \\
\end{array}$ \\
\hline
\end{tabular}

Different letters in the same column denote statistical significance $(P<0.05)$. 
group. Concerning magnesium content in femurs, there were marked increasing in groups 5, 6 and 7 with higher value observed in group 7. These results are confirmed by the results of dietary $\mathrm{Ca}, \mathrm{P}$ and $\mathrm{Mg}$ efficiency percentage, where the treated groups showed significant increases, particularly group 7 for $\mathrm{Ca}$ and $\mathrm{Mg}$ and groups 5 and 7 for $\mathrm{P}$ as compared to control group (Table 8). The present study is in agreement with the previous studies which revealed that although there were no significant differences in ash content, but femur $\mathrm{Ca}$ and $\mathrm{Mg}$ content, dietary $\mathrm{Ca}$ and $\mathrm{Mg}$ efficiency increased significantly among rats consuming diets containing inulin or fructooligosaccharides (Mabrok, 2006). Hirama et al. (2003) reported that high phosphorus content in the surface of cortical bone at the femoral neck was observed in rats after feeding diet containing indigestible carbohydrates. Because butyrate is the major fermentation product of inulin, whereas mostly acetate and lactate are produced on short-chain inulin-type fructans and butyrate is a potent stimulator of calbindin D9K expression and thus of the active calcium absorption pathway mediated via the increase in 1,25 dihydroxycholicalciferol receptor binding activity (Abrams et al., 2005).These findings can explain the advantage of inulin over oligofructose with respect to bone mineralization via this mechanism (Rossi et al., 2005).

In conclusion, supplementation the baby cereal foods with bifidobacteria and Jerusalem artichoke as a source of inulin had a beneficial effect on $\mathrm{Ca}, \mathrm{Mg}$ and $\mathrm{P}$ absorption and retention, particularly at $10 \%$ of Jerusalem artichoke. Consequently, a positive impact on mineral deposition in bone was observed in baby ages. Further studies are needed with other sources of indigestible carbohydrated and other types of probiotics.

\section{REFERENCES}

Abrams S. A., Griffin I. J., Hawthorne K. M., Liang L., Gunn S. K. and Darlington G. (2005). A combination of prebiotic shortand long-chain inulin-type fructansenhances calcium absorption and bone mineralization in young adolescents. American J. Clin. Nut., 82: 471- 476.

A.O.A.C. (2005). Official Methods of Analysis, $18^{\text {th }}$ ed. Association of Official Analytical Chemists, Ins. U.S.A.

Al-Sheraji S.H., Amin Ismail A., Manap M. Y., Mustafa S.,Yusuf R. M. and Hassan F. A.
(2013). Prebiotics as functional foods: A review. J. func. Foods, 5:1542-1553.

Al-Sheraji S. H., Ismail A., Manap M. Y., Mustafa S. and Yusuf R. M. (2012a). Survival and activity of bifidobacteria during refrigerated storage of yoghurt containing Mangifera pajang fibres polysaccharides. J. Food Sci., 77: M624M630.

Al-Sheraji S. H., Ismail A., Manap M. Y., Mustafa S., Yusuf R. M. and Hassan F. A. (2012b). Fermentation and nondigestibility of Mangifera pajang fibres and its polysaccharide. J. Functional Foods, 4: 933-940.

Bohuon C. (1962). Micro determination of magnesium in various biological media. Clinica Chimica Acta, 7:811-817.

Chabbert N., Braun P., Gwraud J.P., Armoux M.and Glazy P. (1983). Productivity and fermentability of Jerusalem artichoke (Helianthus tubersus L.) according to harvesting date. Biomass, 3:209-224.

Chouraqui J.P., Grathwohl D., Labaune J.M., Hascoet J.M. and de Montgolfier I. (2008).Assessment of the safety, tolerance, and protective effect against diarrhea of infant formulas containing mixtures of probiotics or probiotics and prebiotics in a randomized controlled trial. American Journal of Clinical Nutrition. 87 (5):1365-1373.

Dave R.I. and Shah N.P. (1996). Evaluation of media for selective enumeration of Streptococcus thermophilus,Lactobacillus delbrueckii spp. Bulgaricus, Lactobacillus acidophilus and Bifidobacteria. J. Dairy Sci. 79:1529-1536.

Deleenheer L. (1996).Production and the use of inulin.Industrial reality with promising future. In:Production and use of inulin. Reffuberue/ turkenibtiuse, Anadorenstraat I,B-3300 tienen, Belgium, pp:67-91.

Demigné C., Jacobs H., Moundras C., Davicco M. J., Horcajada M. N. and Bernalier (2008). Comparison of native or reformulated chicory fructans, or nonpurified chicory, on rat cecal fermentation and mineral metabolism. Europ J. Nutr., 47: 366-374.

Dutta P., Mitra U., Dutta S., Rajendran K., Saha T. K. and Chatterjee M. K. (2011). Randomised controlled clinical trial of Lactobacillus sporogenes (Bacillus coagulans), used as probiotic in clinical 
practice, on acute watery diarrhea in children. Tropical Medicine and International Health, 16 (5): 555-561.

FAO and WHO. (2001). Evaluation of health and nutritional properties of powder milk and live lactic acid bacteria. Cordoba, Argentina: Food and Agriculture Organization of the United Nations and World Health Organization Expert Consultation Report, pp. 1-34.

Gibson G.R. and Wang X. (1994). Enrichment of bifidobacteria from human gut contents by oligofructose using continuous culture. FEMS Microbiol. Lett., 118: 121-127.

Gopal P.K., Prasad J. and Gill H.S. (2003). Effects of the consumption of bifidobacteriumlactis HN019 (DR100)and galacto-oligosaccharide on the microflora of the gastrointestinal tract in human subjects. Nut. Res., 10: 1313-1328.

Hirama Y. , Morohashi T. Sano T., Maki K., Ohta A. and Sasa R. (2003). Fructoligosaccharides prevent disorders of the femoral neck following gastrectomy in growing rats. Bone and Minerals Metabol. 21: 294-298.

Hurre A., Laitinen K. and Rautava S. (2008). Impact of maternal atopy and probiotic supplementation during pregnancy on infant sensitization: a double-blind placebo-controlled study. Clinical and Experimental Allergy, 38, 1342-1348.

Kim S. H., Lee D. H. and Meyer D. (2007). Supplementation of infant formula with native inulin has a prebiotic effect in formula-fed babies. Asia Pacific J. Clin. Nutr., 16: 172-177.

Leclercq E. and Hageman G. J. (1993). Valorization of an inulin rich byproduct of chicory.In: A.Fuchs (ed), Inulin and Inulin Containing Crops,Elsevier Science Publishers B. V. pp:367-372.

Mabrok H. H.B. (2006). Isolation of inulin and fructooligosaccharides from onion and assessing their biological activities on calcium absorption and bone mineralization. M.Sc. Thesis, Department of Biochemistry, Fac. Of Agric., Cairo Univ., Egypt.

Molnar-Perl J. (2000). The role of chromatography in the analysis of sugar,carboxylic acids and amino acids in food. J. chromato., 891A:1-32.

Nader N. and Youssef M. D. (2007). Childhood and adolescent constipation: review and advances in management. Current Treatment Options in Gastroenterology, 10: 401-411.

Newburg D. S. (2005). Innate immunity and human milk. J. Nutr., 135:1308-1312.

Pascoal G.B., Lajolo F.M. and Menezes E.W. (2005). Effects of fructans derived from onion on indigestible carbohydrates fermentation:in vivo study. In:Proceedings of the 18 international congress of nutrition, nutrition safari for innovative solutions ICC, 19-23 September, Durban, South Africa.

Perez-Conesa D., Ros G. and Periago M. J. (2002). Protein nutritional quality of infant cereals during processing. J. Cereal Sci., 36:125-133.

Raschka L. and Daniel H. (2005). Mechanisms underlying the effects of inulin type fructose on calcium absorption in the large intestine of rats. Bone, 37: 728-735.

Reeves P.G., Nielsen F.H. and Fahey G.C. (1993). AIN-93 purified diets for laboratory rodents: final report of the American Institute of Nutrition ad hoc writing committee on the reformulation of the AIN-76Arodent diet. J. Nutr., 123:1939-1951.

Rideout T.C. and Fan M. Z. (2004). Nutrient utilization in response to dietary supplementation of chicory inulin in growing pigs source. J. Sci. Food and Agric., 84: 1005-1012.

Robberecht H. J., Hendrix P., Van Cauwenbergh R. and Deelstra H.A. (1994). Daily dietary manganese intake in Blegium, using duplicate portion sampling. Z. Lebensm Unters Forsch.,199: 446-448.

Rossi M., Corradini C., Amaretti A. and Matteuzzi D. (2005). Fermentation of frucooligosaccharides and inulin by bifidobacteria: a comparative study of pure and fecal culture. Appl. Environ. Microbiol.71:6150-6158.

Saarela M., Virkajarvia I., Alakomi H-L. and Jaana Matto P.S.M. (2006). Stability and functionality of freeze-dried probiotic Bifidobacterium cells during storage in juice and milk. Int'l Dairy J., 16: 14771482.

Scholz-Ahrens K.E., Acil Y. and Schrezenmeir J.(2002). Effect of oligofructose or dietary calcium on repeated calcium and phosphorus balances, bone mineralization and trabecular structure in ovariectomized 
rats. British J. Nutr., 88: 365-378.

Scholz-Ahrens K.E. and Schrezenmeir J. (2007). Inulin and oligofructose and mineral metabolism: The evidence from animal trials. J. Nutr., 137: 2531S- 2523S.

Snedecor G.W. and Cochran W.G.(1989). Statistical methods 9.the lowa state university press. Ames, lowa.

Steed H., Macfarlane G. T., Blackett K. L., Bahrami B., Reynolds N. and Walsh S. V.(2010). Clinical trial: the microbiological and immunological effects of synbiotic consumption - a randomized double-blind placebocontrolled study in active Crohn's disease. Alimentary and Pharmacology Therapeutics, 32(7): 872-883.

Sykora J., Valeekova K. K. V. and Amlerova J. J. A. (2004). Supplements of a one week triple drug therapy with special probiotic Lactobacillus caseiimmunitass (strain DN 114000) and Streptococcus thermophiles and Lactobacillus bulgaricusin the eradication of $H$. pylori-colonized children: a prospective randomised trial. J. Pediatric Gastr. Nutr., 39 (Suppl. 1), 400.

Tako E., Glahn R. P., Welch R. M., Lei X., Yasuda K. and Miller D. D. (2008). Dietary inulin affects the expression of intestinal enterocyte iron transporters, receptors and storage protein and alters the microbiota in the pig intestine. British J. Nutr., 99: 472-480.

Weatherburn M.W., Baker P.J. and Logan J.E. (1982). Serum calcium methodologya canadian assessment based on the application of the reference method. Clin. Biochem., 15 (4):222-229.

Younes H., Coundray C. and Rayssigure Y. (2001). Effects of two fermentable carbohydrates (inulin and resistant starch) and their combination on calcium and magnesium balance in rats. British J. Nutr. 86: 479-485.

\section{تأثيرامداد أغذية الفطام بالمدعمات الحيوية ومنشطاتها على امتصاص بعض المعادن نهلة عبد الفتاح البستانى}

قسم الأغذية الخاصة والتغذية ـ معهد بحوث تكنولوجيا الأغذية ـ ـركز البحوث الزراعية ـ الجيزة- مصر

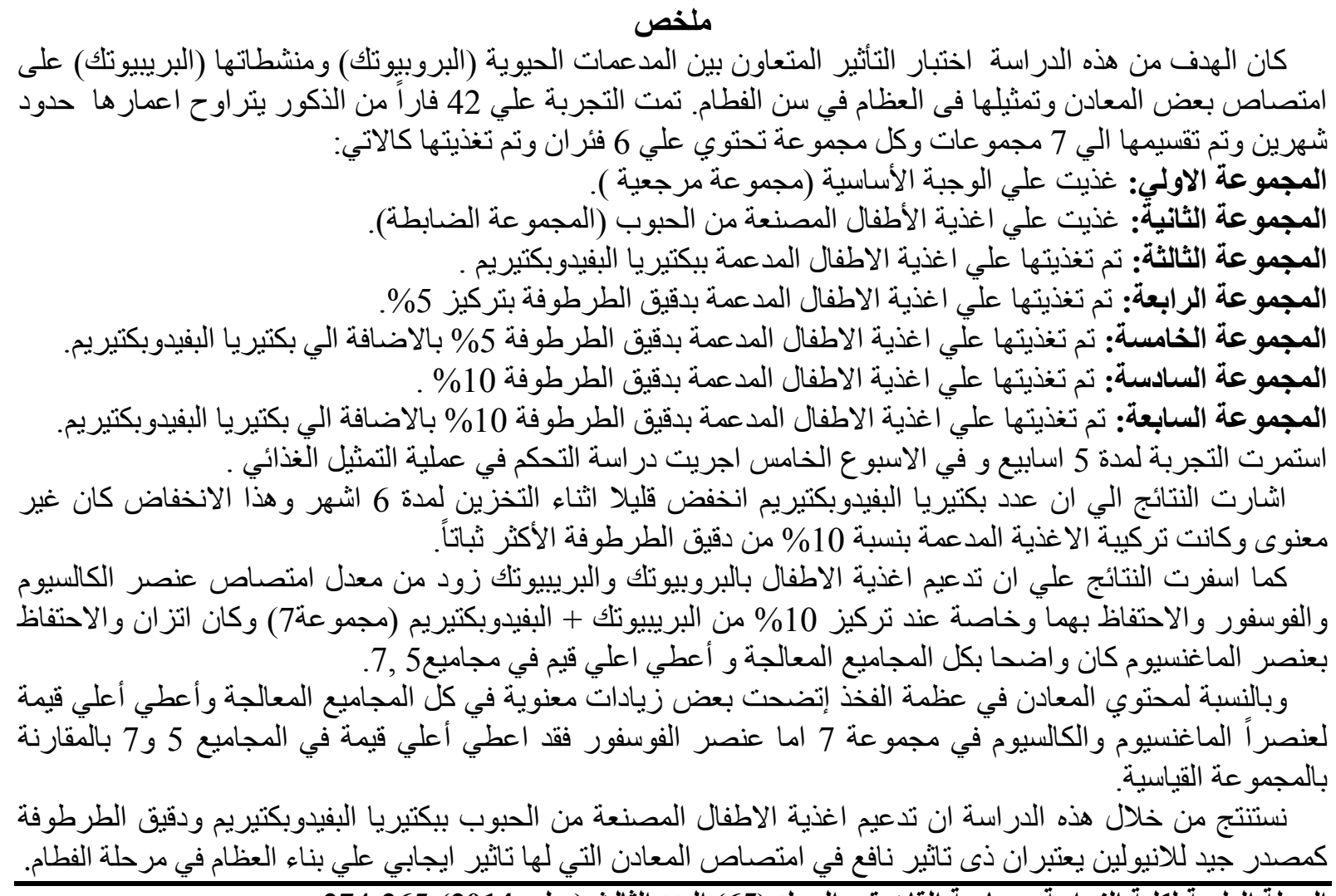

